\title{
Factors Affecting the Adoption of Agricultural By-Products as Feed by Beef Cattle Farmers in Maros Regency of South Sulawesi, Indonesia
}

\author{
S. Baba ${ }^{a, *}$, M.I.A. Dagong ${ }^{b}$, S. Sohrah ${ }^{c}, \&$ R.F. Utamy ${ }^{b}$ \\ ${ }^{a}$ Department of Socio Economic, Faculty of Animal Science, Hasanuddin University, \\ ${ }^{b}$ Department of Animal Production, Faculty of Animal Science, Hasanuddin University, \\ Jalan Perintis Kemerdekaan, KM 10, Makassar 90245, South Sulawesi, Indonesia \\ 'Department of Agribussines, Maros Muslim University, \\ Jalan Dr. Ratulangi No. 62 Maros, South Sulawesi, Indonesia \\ *Corresponding author: syahdarbaba@gmail.com \\ (Received 16-04-2018; Revised 08-11-2018; Accepted 11-11-2018)
}

\begin{abstract}
The utilization of crop residue as a feed is very important because the arable land area is relatively limited. The study was aimed to examine the influence of adoption of crop-residue product as a feed. The research was conducted in Maros District by using survey methods from March to August 2015. The number of respondents was 96 farmers scattered throughout the Districts of Bantimurung and Camba as centers of rice, corn plant, and cattle productions. Questionnaires were used to collect data conducted by a trained enumerator. Survey was arranged using a logistic regression model to identify socio economic factors influencing the adoption of crop residue as a feed. Work perception (X2), contact with extension workers (X4), rice cultivated areas (X5), the number of livestock (X6), subjective norm (X7), and difficulty (X8) were socio-economic variables influencing the adoption of crop residue as a feed. However, the variables age (X1), farmer experiences (X3), and the number of family members (X9) had no effect on the adoption of this technology. In conclusion, extension workers play an important role in increasing the adoption of technology by using rice and corn straws as a feed. Likewise, not only the number of livestocks, but also the good perception of the farmers increased along with the increase of feed availability, such as utilization of rice and corn straws.
\end{abstract}

Keywords: technology adoption; crop residue; fodder; Maros

\section{INTRODUCTION}

Generally, in Indonesia, smallholder beef farmers hold a limited number of livestock, approximately 2-3 heads in total (Direktorat Jenderal Peternakan, 2015). The smallholder beef farmers face many obstacles to increase their numbers of livestock. In the past 10 years (2003-2013), extensive pasture had not been increasing and only 3.05 million hectares were available, concentrated in a few provinces (National Statistical Bureau, 2014). Arable grassland is relatively limited and the nutritive values of forage crops vary between seasons, with significant qualitative and quantitative drops in the dry season. Native pastures provide herbage production for cattle. However, this function has significantly decreased due to the shift of function from native pasture to horticulture and crop fields or settlements, resulting in a shortage of herbage production (Haryanto, 2009). Therefore, the utilization of crop residues such as rice and corn straws could be an alternative feed supply for smallholder beef farmers that can support the increase in the number of their livestock.

The utilization of crop residues such as rice and corn straws as a feed is a well- known method. In
India, crop residue reached $50 \%-60 \%$ of total feed used so that breeding strategy towards the development of dual-purposes plant types could increase the adoption of improved varieties (Rao \& Hall, 2003), while in Indonesia the use of rice straw for animal feed just reached 31\%-39\%. Since 1990-2000, Indonesian Agency for Agricultural Research and Development, Ministry of Agriculture, introduced the Crop Livestock System, (CLS program; integrated rice/corn beef) in several provinces, including South Sulawesi (Haryanto, 2009; Winarso \& Basuno, 2013; Baba et al., 2014). However, the utilization of straw as feed causes shortages of the straw and smallholder beef farmers usually do not store the straw as a feed reserve for the following season (Haryanto, 2009). Even in the agricultural intensification land which produces high biomasses, the availability of feed for beef cattle is relatively limited (Ralevic et al., 2010; Valbuena et al., 2012).

Maros is one of the well-known districts in South Sulawesi which is either as a center of rice crops or as a Bali beef cattle development center. In 2015, the rice harvest area reached 47,648 ha with Bantimurung District had the highest harvest area i.e., 18.31\% (BPS, 2015). In 2007-2011, Farmer Empowerment through 
Agriculture Technology Information (FEATI) encouraged smallholder beef farmers to use rice and corn straws as feeds. Furthermore, in 2012-2013, a participatory approach was used by the University of Hasanuddin to develop the technology. The researchers, extension workers, and smallholder beef farmers not only identified the feed potential, but they also conducted some experiments at the farmer level. After the experiments, the smallholder farmers evaluated the technologies which had been developed and decided whether to adopt the technology or not (Rhoades \& Boath, 1982; He et al., 2009). The participation of extension workers not only increases the access to resources (Hauser et al., 2016) but also the adoption of the technology (Atmis et al., 2009; Bremer et al., 2014). However, in Maros, the adoption of crop residue to be used as a feed is still limited. Baba et al. (2014) revealed that utilizations of rice and corn straws as feeds were only $63.5 \%$ and $32.5 \%$, respectively.

The success of crop residues utilization as a feed is influenced by several social, economic, and technical factors; for example, the difficulty in making rice straw compost (Supaporn et al., 2013), unclear economic benefits (Giller et al., 2009), labor shortages for processing of straw as a feed, and a lack of knowledge about the processing of the straw (Supaporn et al., 2013; Baba et al., 2014; Mudzengi et al., 2014). It also includes the cost of implementation and expected benefits. Interest from smallholder farmers and their perceptions, as well as demographic characteristics, have been a factor (Giller et al., 2009). Socio economic factors were the main factors that are the determinant of technology adoption. The adoption of crop residue utilization as a feed has never been done yet in Maros. Therefore, the objective of this study was to determine the socio-economic impact of farmers to adopt the utilization of crop residues as feed.

\section{MATERIALS AND METHODS}

\section{Data Collection}

This research was conducted in Maros District, South Sulawesi. The selected site is a well-known center for rice crop productions, corn, and Bali beef cattle in Eastern Indonesia. Previously, collaboration between the University of Hasanuddin, Maros District Government, and the Assessment Institute for Agricultural Technology, South Sulawesi Province disseminated utilization of rice and corn straws as a feed. The dissemination included fermentation and ammonization of rice and corn straws and silage of corn stalk. In this district, December-March is the first cropping of paddy; April-June is the second cropping of sticky corn, pulut, local name of sticky corn; and July-September is the third cropping of corn, respectively. Pulut is harvested in young stage (70 days); therefore, it has a high palatability.

Data collection used questionnaires which were distributed by trained enumerators, running from March to December 2015. In total, 487 smallholder beef farmers were spread over three sub-districts such as Simbang and Bantimurung (2 villages) and Camba
(1 village). Overall, 96 farmers were selected as respondents from each village using quota sampling. In Samangki and Simbang (Subdistrict Simbang), there were 25 and 20 respondents, respectively; in LeangLeang and Minasa Baji (Subdistrict Bantimurung) there were 23 and 16 respondents, respectively; and in Pattiro Deceng (Subdistrict Camba), there were 12 respondents.

\section{Statistical Analysis}

Adoption of technology is the decision of farmers to accept or reject technology. The decision to the adoption of technology is influenced by many factors such as environmental factors, smallholder-farmers characteristics, socio-economics, farming purposes, biophysics, and technology delivery method to the farmers. Dependent variables (i.e. adoption and utilization of crop-residues technology) were measured by using dichotomous model where 1 meant was adopted while 0 meant was not adopted. Independent variables were internal factors of farmers, socio economy of the farmers, and biophysical farming. These factors were determined because of the cattle business and paddy field had long been carried out by them even though it had not been well integrated yet. Therefore, whether adopted or not adopted the technology of crop residue utilization depends on internal factors, socio-economic, and the biophysics of their farming.

Logistic regression model was used for determination of factors influencing the adoption of crop residues as a feed. Logistic model was used as the dependent variable measured by dichotomous variables, where 0 meant was not adopted (unused crop residues as a feed), while 1 meant was adopted (used crop residues as a feed the whole time). The logistic regression model was as follows:

$Y=\ln \left(\right.$ pi $/ 1$-pi) $=\beta_{0}+\beta_{1} X_{1}+\beta_{2} X_{2}+\beta_{3} X_{3}+\beta_{4} X_{4}+\beta_{5} X_{5}+$ $\beta_{6} X_{6}+\beta_{7} X_{7}+\beta_{8} X_{8}+\beta_{9} X_{9}+\varepsilon$

Where: $Y$ was the opportunity for adoption or the utilization of straw as feed ( $\mathrm{pi}=0$ indicated no adoption, $\mathrm{pi}=1$ indicated adoption); $\beta_{0}$ was intercept; $\beta_{1}-\beta_{7}$ was regression coefficient of the dependent variable; $X_{1}$ was age, expressed of the length of their life (year); $X_{2}$ was work perception, as a dichotomous variable, where 1 denoted the main work as being a beef cattle farmer, and 0 otherwise; $X_{3}$ was farmer experience, reported as the length of their experience as a beef cattle farmer (years); $\mathrm{X}_{4}$ was contact with extension workers, expressed as the number of contacts with extension workers (frequency in 2015); $X_{5}$ was rice cultivated area, expressed as the number of hectares (ha); $X_{6}$ was the number of cattle, expressed as the number of cattle intensively reared (heads); $X_{7}$ was subjective norm, expressed as the perception of beef cattle farmers towards what should be done in view of their community based on their position (score); $\mathrm{X}_{8}$ was technology difficulties, expressed as a difficulty in using crop residues feed by beef cattle farmers: 1 if they agree that it is difficult, or 0 if otherwise; and $X_{9}$ was family size, expressed as the number of farmers' family (individual). 


\section{RESULTS}

\section{Farmer Characteristics}

There were no significant differences between age, farmer experience, family size, and the education level of the farmers whether adopters or non-adopters. However, the number of cattle and rice cultivated area of adopter farmers was significantly higher than that of the non-adopter farmers (Table 1). The number of cattle increased as the amount of feed increased such as rice straw. On the contrary, the availability of labor was not a distinguished factor between adopters and non-adopters.

\section{The Farmer's Reasons to Adopt and Not Adopt}

There were many reasons for smallholder beef farmers to adopt the utilization of crop residue such as corn-straw as a feed (Table 2). The first reason was the shortage of land fodder or herbage production. The second reason was the limited of land fodder holding and the third was the increase in corn straw with the increase in harvesting season.

The main reason for smallholder beef farmers not adopting straw as a feed was the availability of the other feed sources such as Napier grass and Native grass (Table 3). In addition, the farmers did not only require labor to collect rice and corn straws, but they also had no free time. Another reason was the non-available facility for feed storage. Jabbar et al. (2009) stated that labor is one of the factors why farmers did not adopt the utilization of crop residue as a feed.

\section{Factors Affecting Farmers to Adopt Crop Residue as Feed}

The results of the overall correct prediction (88.7\%) and Chi square statistics (93.742) showed that the models had the high ability to predict the chance to adopt the utilization of rice and corn straws as feed in Maros District. R square (0.709) showed that $70.9 \%$ variation in the dependent variables was determined by the selected independent variables. Wald indication stated that contact with the extension (12.507) and the number of cattle (11.506) variables had a greater influence on the farmer's adoption of rice and corn straws as a feed (Table 4).

Logistic regression analysis showed that 6 out of 9 independent variables had significant effects on the adoption of straw as a feed. The 6 variables were contact with the extension worker $(P<0.01)$, the number of cattle $(P<0.01)$, rice cultivated area $(P<0.01)$, subjective norms $(P<0.01)$, work perception $(P<0.05)$, and the level of technology difficulty in processing straw $(P<0.05)$. Contact with extension workers, the number of cattle, rice cultivated area, social norms, and work perceptions had positive regression coefficient values indicating that they had positive influences on the adoption of straw as a feed. These results indicated that the increased contact with the extension agents, the number of cattle, the increase of rice cultivated area, social norm, and the higher perception of farming would increase the adoption of straw as feed.

Table 1. Characteristics of farmers and business farming by respondents

\begin{tabular}{|c|c|c|c|c|c|}
\hline \multirow{2}{*}{ Variable } & \multicolumn{2}{|c|}{ Adopter } & \multicolumn{2}{|c|}{ Non Adopter } & \multirow{2}{*}{ T-Test } \\
\hline & Mean & Std & Mean & Std & \\
\hline Age (Year) & 43.45 & 9.10 & 43.13 & 10.65 & $0.386^{\mathrm{ns}}$ \\
\hline Business experience (year) & 6.36 & 4.94 & 5.54 & 3.31 & $0.270^{\mathrm{ns}}$ \\
\hline Family member (person) & 4.09 & 1.21 & 3.67 & 1.13 & $0.914^{\mathrm{ns}}$ \\
\hline Number of cattle (head) & 3.86 & 1.17 & 2.98 & 0.75 & $0.000^{* *}$ \\
\hline Wide of rice areal (are) & 49.68 & 33.37 & 27.38 & 18.29 & $0.003^{* *}$ \\
\hline \multicolumn{6}{|l|}{ Education level (person) } \\
\hline Low ( $\leq$ junior high school) & \multicolumn{2}{|c|}{36} & \multicolumn{2}{|c|}{43} & \\
\hline Senior high school & \multicolumn{2}{|c|}{7} & \multicolumn{2}{|c|}{9} & \\
\hline University & \multicolumn{2}{|c|}{1} & \multicolumn{2}{|c|}{0} & \\
\hline Total of farmers & \multicolumn{2}{|c|}{44} & \multicolumn{2}{|c|}{52} & \\
\hline
\end{tabular}

Note: t-test ns= Non-significant; ${ }^{*}$ significant in level $0.05(\mathrm{P}<0.05),{ }^{* *}$ significant in level $0.01(\mathrm{P}<0.01)$.

Table 2. Farmer's reasons for using crop residue as feed

\begin{tabular}{lcc}
\hline Reason of adoption & Score $^{*}$ & Rank \\
\hline Herbage production becomes in shortage & 168 & 1 \\
Holding limited land fodder & 160 & 2 \\
Obtainable of corn-straw & 153 & 3 \\
Straw abundant & 110 & 4 \\
Spend of leisure time & 69 & 5 \\
\hline
\end{tabular}

Note: The scale of 5-1 provided from the most important or vice versa in any respondents who adopted (44 respondents).
Table 3. The farmer's reason for not adopting the use of rice and corn straws as feed

\begin{tabular}{lcc}
\hline Reason of non-adoption & Score & Rank \\
\hline The sufficient of the other feed sources & 207 & 1 \\
Pasture & 197 & 2 \\
Labor to collect straw & 149 & 3 \\
No storage place for feed & 140 & 4 \\
Required surcharge for storage of straw & 87 & 5 \\
\hline
\end{tabular}

Note: The scale of 5-1 provided from the most important or vice versa in any respondents who adopted (52 respondents). 
Table 4. Logistic regression coefficients of the factors affecting the adoption of utilization of crop residue as feed

\begin{tabular}{lcccc}
\hline \multicolumn{1}{c}{ Variable } & B & SE & Wald indication & P-Value \\
\hline Age (X1) & -0.006 & 0.028 & 0.048 & $0.827^{\text {ns }}$ \\
Work perception (X2) & 1.918 & 0.859 & 4.988 & $0.026^{*}$ \\
Farmer experience (X3) & 0.039 & 0.099 & 0.154 & $0.695^{\text {ns }}$ \\
Contact with extension worker (X4) & 2.835 & 0.802 & 12.507 & $0.000^{* *}$ \\
Rice cultivated area (X5) & 0.058 & 0.022 & 7.179 & $0.007^{* *}$ \\
Number of cattle (X6) & 2.328 & 0.392 & 11.506 & $0.001^{* *}$ \\
Subjective norm (X7) & 1.697 & 0.638 & 7.075 & $0.008^{* *}$ \\
Technology difficulties (X8) & -1.246 & 0.601 & 4.295 & $0.038^{*}$ \\
Family size (X9) & 0.035 & 0.336 & 0.011 & $0.918^{\text {ns }}$ \\
Constant & -13.99 & 3.498 & 15.993 & $0.000^{* *}$ \\
\hline
\end{tabular}

Note: ${ }^{* *}$ and ${ }^{*}=$ significant at $\mathrm{P}<0.01$ and $\mathrm{P}<0.05$, respectively; -2 likelihood is 77.351 ; chi square statistic is $93.742^{* *}$; Nagelkerke $\mathrm{R}$ Square 0.709 ; Overall correct prediction is 88.7 ; the number of observation= 96 ; $\mathrm{B}=$ coefficient value; $\mathrm{SE}=$ standard error.

On the other hand, the level of difficulty in processing straw showed a negative coefficient (Table $4)$. The higher the difficulty in handling rice and corn straws, the lower the success in adopting rice and corn straws as feed. The variables which did not significantly affect the adoption of straw as a feed were age, farmer experience, and the family size.

\section{DISCUSSION}

The success of the beef cattle farmers in adopting technology to use straws as a feed depends on the adequacy of feed for cattle. If the farmers lack feeds such as grasses, they will use rice straw and corn straw as the main feed source (44 respondents). The method used by the farmers to manage straw was as follow: 1) neither planting spot nor harvesting period was the same; 2) planting time of corn should be different among farmers for collecting corn straw; and 3) cultivation and storage of straw.

The main reason for smallholder beef farmers not adopting straw as a feed is the availabilities of the other feed sources such as Napier grass and native grass. Smallholder beef farmers plant Napier grass close to their cattle pens so that it is easier to be harvested or the livestock can graze in field twice a day. There were 28 farmers $(53.85 \%)$ who prepared pasture for livestock grazing during the day, and therefore this condition did not require any additional feeds. Generally, farmers who hold a limited number of livestock do not adopt straw as a source of feed (Table 1); however, there was a shortage in herbage production when compared to the farmers who had large farm scales.

Coefficient value of the intensity of contact with the extension worker was 2.835. The value means that farmer who has a contact with the extension worker had 2.835 times opportunity to adopt compared to the other farmers who did not have any contacts with the extension worker. Extension worker is one of the important sources of information for farmers. Adequate information especially from extension workers is one of the key drivers of technology utilization in Maros (Rogers 2003; Feola \& Binder, 2010). They work for the farmer's needs, not only demonstrating the utilization of the straw as a feed, as counselors, and as assistants, but also they help the farmers to identify and solve the problems they have in the field (Bodorkos \& Pataki, 2009; Hauser et al., 2016).

The number of livestock is one of the factors which play an important role in the adoption and use of crop residue as feed. The variable coefficient of the number of livestock was 2.328 . The value means that the farmers who have more livestock have 2.328 times opportunity in adopting rice and corn straws as feed compared to farmers who have less livestock. The demand of feed increased with the increase in the number of livestock. Rice and corn straws are two alternative crop residues to meet the feed demand in Maros District (Table 2). To meet the needs of cattle, rice and corn straws have to be processed before being given to cattle because of their poor qualities (Haryanto, 2009). Parmawati et al. (2018) reveal that region as the center of developing food security, such as Pasuruan, is able to support the availability of feed for livestock and the integration programs between livestock and crop.

The perception of livestock business is one of the drivers of farmer to adopt the utilization of rice straw as feed. The value of variable perception is 1.918 , which means that the higher the value of farmer's perception towards their farming the higher the probability they will adopt the formulated rice and corn straws as feed i.e., it will increase 1.918 times. The farmers whose livestock business is the primary source of their income will maintain their livestock properly through the provision of sustainable feed. For instance, rice and corn straws will be collected by the farmers not only in their rush hours but also in their free times. According to Reimer et al. (2012), a good perception is increased by the increase of farmers' motivation through the utilization of free time for their farming.

The obstacle factor in adopting rice and corn straws as feed is a high level of difficulty especially when collecting and formulating rice and corn straws. Coefficient level of difficulty was -1.246 . The coefficient means it have a negative correlation with the adoption of rice and corns straws: the success in adoption of rice and corn straws as feed will decrease by 1.2 times with the increased level of difficulties. The lack of labor and straw barns were the reason for the farmer not adopting 
the utilization of rice and corn straws as feed (Table 3). However, the need for a labor to process corn straw was the main factor inhibiting the utilization of corn straw as feed (Mudzengi, 2014).

\section{CONCLUSION}

In Maros Regency, extension workers play an important role in increasing the adoption of technology in using rice and corn straws as a feed. Likewise, not only the number of livestock, but also the good perception of the farmers increased along with the increased feed availability, such as utilization of rice and corn straws. However, it decreased with the increased labor need and the unavailability of straw barns. Therefore, to increase the adoption of technology in using rice and corn straws as a feed, extension workers must support the farmers' skill.

\section{CONFLICT OF INTEREST}

The authors declare there is no conflict of interest.

\section{REFERENCES}

Atmiş, E., H.B. Günşen, B.B. Lise, \& W. Lise. 2009. Factors affecting forest cooperative's participation in forestry in Turkey. Forest policy and economics 11:102-108. https:// doi.org/10.1016/j.forpol.2008.10.002

Baba, S., S.N. Sirajuddin, A. Abdullah, \& M. Aminawar. 2014. Barrier to adoption of integration of maize-livestock in Maros, Gowa and Takalar Regency. JITP Vol. 3 No. 2: 114-120.

Bodorkos, B. \& G. Pataki. 2009. Linking academic and local knowledge: community-based research and service learning for sustainable rural development in Hungaria. J. Clean. Product. 17:1123-1131. https://doi.org/10.1016/j. jclepro.2009.02.023

Bremer, L.L., K.A. Farley, \& Lopezz-Carr David. 2014. What factors influence participation in payment for ecosystem services programs? An evaluation of Ecuador's Socio Paramo program. Land Use Pol. 36:122-133. https://doi. org/10.1016/j.landusepol.2013.08.002

Direktorat Jenderal Peternakan. 2015. Data Populasi Ternak di Indonesia. Dirjen Peternakan, Kementerian Pertanian Republik Indonesia, Jakarta.

Feola G. \& C.R. Binder. 2010. Towards and improved understanding of farmer's behavior: The integrative agent-centered (IAC) framework. Ecol. Econ. 69:2323-2333. https:// doi.org/10.1016/j.ecolecon.2010.07.023

Giller, K.E., E. Witter, M. Corbeelsand, \& P. Tittonell. 2009. Conservation agriculture and smallholder farming in Africa:the heretics'view. Field Crops Res. 114:23-34. https://doi.org/10.1016/j.fcr.2009.06.017

Hauser, M., M. Lintdner, S. Prehsler, \& L. Probst. 2016. Farmer participatory research: why extension workers should understand and facilitate farmer's role transitions. J. Rural Stud. 47:52-61. https://doi.org/10.1016/j. jrurstud.2016.07.007
Haryanto, B. 2009. Inovasi teknologi pakan ternak dalam sistem integrasi Tanaman-Ternak bebas limbah mendukung upaya peningkatan produksi daging. Pengembangan Inovasi Pertanian 2:163-176.

He, J., Z. Zhou, H. Weyerhaeuser, \& J. Xu. 2009. Participatory technology development for incorporating non-timber forest products into forest restoration in Yunnan, Southwest China. For. Ecol. Manage. 257:2010-2016. https://doi. org/10.1016/j.foreco.2009.01.041

Mudzengi, C.P., L.M. Taderera, A. Tigere, C.S. Kapembeza, S. Moyana, M. Zimondi, E.T. Derembwe, \& E. Dahwa. 2014. Adoption of urea treatment of maize stover technology for dry season supplementation of cattle in Wedza, Zimbabwe. Livestock Research for Rural Development. Volume 26, Article \#160. http://www.lrrd.org/lrrd26/9/ mudz26160.htm

National Statistical Bureau - BPS. 2014. Statistik Indonesia. https://www.bps.go.id/publication/2014/05/05/8d2c08d9d 41aa8c02fad22e7/statistik-indonesia-2014.html

National Statistical Bureau - BPS. 2015. Statistik Padi Kabupaten Maros Tahun 2014. Badan Pusat Statistik Kabupaten Maros, Maros.

Supaporn, P., T. Kobayashi, \& C. Supawadee. 2013. Factors affecting farmer's decisions on utilization of rice straw compost in Northeastern Thailand. J. Agr. Rural Develop. Trop. Subtrop. 114-1:21-27.

Parmawati, R., Mashudi, A. Budiarto, Suyadi, \& A.S. Kurnianto. 2018. Developing sustainable livestock production by feed adequacy map: A case study in Pasuruan Indonesia. Trop. Anim. Sci. J. 41:67-76. https://doi. org/10.5398/tasj.2018.41.1.67

Ralevic P., S. G. Patiland, \& G. van Loon. 2010. Integrated agriculture production systems for meeting household food, fooder and fuel security. J. Sust. Agric. 34: 878-906. https:// doi.org/10.1080/10440046.2010.519203

Reimer, A.P., D.K. Weinkauf, \& L.S. Prokopy. 2012. The Influence of perceptions of practice characteristics: An examination of agriculture best management practice adoption in two Indiana watersheds. J. Rural Stud. 28:118-128. https://doi.org/10.1016/j.jrurstud.2011.09.005

Rhoades, R.E. \& R.H. Boath. 1982. Farmer-back-tofarmer: a model for generating acceptable agriculture technology. Agr. Admin. 11:127-137. https://doi. org/10.1016/0309-586X(82)90056-5

Rogers, E. M. 2003. Diffusion of Innovations. Fifth Ed., New York Press, New York.

Valbuena D, O. Erensteinb, S. Homann-Kee Tuic, T. Abdoulayed, L. Claessense, A.J. Duncang, B. Gérarda, M.C. Rufinoh, N. Teufeli, A. van Rooyencand, \& M.T. van Wijkh. 2012. Conservation agriculture in Mixed croplivestock systems: Scoping crop residue trade-offs in subsaharan Africa and South Asia. Field Crops Res. 132:175184. https://doi.org/10.1016/j.fcr.2012.02.022

Winarsoh, B. \& E. Basuno. 2013. Pengembangan pola integrasi Tanaman-Ternak merupakan bagian upaya mendukung usaha pembibitan sapi potong dalam negeri. For. Penelitian Agroekonomi 31:151-169. https://doi. org/10.21082/fae.v31n2.2013.151-169 